\title{
NHS International Hospital Branding Image Strategy Through Integrated Marketing Communication
}

\author{
Niken Sasadhara Sasmita ${ }^{1,}$, , Santi Isnaini ${ }^{2}$, Irfan Wahyudi ${ }^{3}$ \\ ${ }^{1}$ Master of Media \& Communication, Universitas Airlangga, \\ 2,3 Communication Studies, Universitas Airlangga, dst. \\ Email: nikensasadhara@gmail.com
}

\begin{abstract}
This article results from research on the brand image strategy carried out by the National Hospital Surabaya (NHS) through integrated marketing communications. This study is on health services bases in the community currently entering the industrial and business era. The main problem arises in-hospital services, which have developed into an industry and are profit-oriented. This problem puts pressure on hospital managers and owners, especially on the cost dimension in private hospitals. Private hospitals must continue to improve management capabilities in carrying out hospital operations with good quality standards to the best compared to other hospitals. The research uses a case study research method with a qualitative approach. Data collection and analysis techniques use observation and in-depth interviews so that they can be analyzed exploratively. The results of this study are the first are there are many reasons why the marketing department of NHS adopts Integrated Marketing Communication (IMC) in their sales strategy. It also happens in the healthcare industry, namely hospitals. One of the reasons that become the basis is that marketers understand and recognize strategies integrating into various communication functions rather than running these communication functions alone. Second, marketing communication theory becomes the rationale for processing data and analyzing the phenomenon of problems regarding strategic concepts in policy determination to the direction of marketing communication strategies carried out by NHS hospitals. This research concludes that the main problem arises in hospital services, which have developed into an industry and are profit-oriented. Strategic management skills will become more critical as pressure increases to find future revenue and growth opportunities. These opportunities will come through various combinations of new healthcare products and services, increasing penetration into high-priority market segments, or accessing new markets that are not serving currently.
\end{abstract}

Keywords: Brand Image; National Hospital Surabaya; Integrated Marketing Communication; Health Services; Industrial and Business

\section{INTRODUCTION}

Health services to the community are currently entering the industrial and business era. Significant problems arise in- hospital services which have developed into industries and are profit-oriented. This problem puts pressure on hospital managers and owners, especially on the cost

ISSN 2338 - 0861 (cetak); e-ISSN 2621 - 8712 (online)

website : http://spektrum.stikosa-aws.ac.id 
dimension in private hospitals. Private hospitals must continue to improve management capabilities in carrying out hospital operations with good quality standards to the best compared to other hospitals. Based on data from the Directorate General of Health Services at the Ministry of Health of the Republic of Indonesia, 2395 public hospitals in Indonesia with private or other ownership are 758 hospitals (source:

http://sirs.yankes.kemkes.go .id/fo/, last access: 26 April 2021).

National Hospital Surabaya is one of the private hospitals in Surabaya, East Java which also feels the impact of intense competition in the health care market. National Hospital Surabaya includes the 14 best hospitals in Surabaya (source: merdeka.com, last access 1 April 2021). National Hospital Surabaya (after this written by NHS) feels the impact of competition in the health care market between private hospitals, especially in East Java as the province with the most significant increase in the number of hospitals in Indonesia. NHS was founded in 2012 and is committed to providing the best health services with sincerity. This hospital has a modern hospital concept supported by international standard equipment. The priority of health services is the needs and comfort of patients in their care.

The condition of hospital competition in Indonesia places a separate phenomenon in the NHS.
NHS carries the vision of "Being a National Pride Healthcare Partner" and the mission of "Providing comprehensive health services with a focus on patients and building people," becoming a paradox in itself because the NHS is also internationally oriented. The hospital's name using a foreign language (English) and the NHS statement that together with the vision, mission, and values raised, the NHS is moving to develop the National Hospital as one of the modern international standard health care facilities in Surabaya and Indonesia. In 2010, the government issued a policy on international hospital naming. Famous doctors are placing and practicing in a hospital, hoping that this doctor will become a referral and person sought after by patients, and the hospital will develop. The NHS is very different, with the starting point of the strategy being in branding hospitals that provide the best health care. Building trust in health services in the community takes time, time frame analysis of a good health service business to be carried out optimally. Hospital health services with modern management cannot be done right away, as in the past, with a wellknown doctor entering the hospital, it will run immediately.

The NHS continues to make branding efforts in a modern way different from the hospital management in the past. The name National Hospital has become a national pride so that it makes 
people put their trust in the health services provided by the NHS. The best service felt at the international home abroad can be provided by the NHS. Communities with high incomes and those who can afford it usually need health services at overseas hospitals. Currently, the NHS can provide it without having to leave the country. The hospital can provide health services with international standards. An international standard hospital is a hospital that has met the standards of the Joint Commission International Accreditation Standards for Hospitals (JCI). The JCI standards serve as the basis for an evaluation process that can help health care organizations measure, assess, and improve hospital performance. JCI's goal is to develop standards that promote quality and ensure patient safety. JCI standards set clear expectations for the organization that is reasonable, achievable, and measurable (DONAHUE \& Vanostenberg, 2000).

The orientation of the current accreditation standard is still the national one even though the services provided meet international standards. The NHS has met accreditation standards in Indonesia, such as the SNARS (National Standard for Hospital Accreditation) issued by KARS (Hospital Accreditation Commission). The legal basis for implementing hospital accreditation is Law no. 36 of 2009 on health, Law no. 44 of 2009 concerning hospitals, and Permenkes 1144/ Menkes/ Per/ VIII/ 2010 concerning the organization and work procedures of the ministry of health. The facilities and infrastructure owned by the hospital must be up to standard. The current strategic vision of the NHS is in line with the vision of the founders of the NHS, which is to be the pride of Indonesia by providing health services (facilities and infrastructure) with the best standards in Indonesia. This standard meets the international standard, namely the JCI standard. The NHS has also provided the best health services for foreign (International) patients. Data for 2019 NHS has provided services to foreign patients by $3 \%$ of the total patients in 2019. Even some patients specifically come to the NHS from abroad to perform health services (surgery).

Neurosurgery services in the NHS are the flagship health service of hospitals. This service is most demanding by patients both domestically and abroad. It means that the definition of an international standard service must have an international standard hospital certificate and be able to provide the best service through international standard facilities and infrastructure. The hospital is one of the companies whose initial goal is a non-profit company. A hospital or health service facility is a health service facility. This service is a socioeconomic unit containing moral 
norms and ethical norms, both organized by the government and the community. In their current development, hospitals, especially private hospitals, are no longer non-profit companies engaged in the social sector (Hermawati, Utari, \& Arifin, 2013).

Competition in the health care market and the growth or increase in the number of hospitals in East Java make NHS hospitals must be able to improve the quality and quantity of health services for the community. To continue to compete in the market for public health services, the NHS consistently and strategically informs the public of the best services like the NHS' flagship health product. NHS efforts continue to achieve a brand image as a hospital with the best services shown and communicated to the broader community. The positive NHS brand image is communicated through integrated marketing communications using integrated communication media to build an international hospital brand image (Nabilah, Bintoro, Indrawan, \& Hariyanti, 2020).

The NHS's marketing communication strategy is also carrying out by other hospitals, both public and private hospitals. The biggest challenge is to build the brand image of the NHS hospital so that it can be known in the community, especially the brand image of international hospitals cannot be realized quickly and in a moment. It is necessary to plan a mature marketing communication strategy and monitor-evaluate continuously. These phenomena and problems are the background of this research, namely, how the NHS carries out the integrated marketing communication strategy (IMC) to build an International Hospital Brand Image (Andrologi \& SUGIARTO, 2014; Lipiäinen \& Karjaluoto, 2015).

Marketing communication activities are an essential part of building a brand image of health services, in this case, the health services provided by the NHS. Due to increased competition in the healthcare market, consumers are becoming more selective in making choices. Data released by the Indonesian Hospital Association (PERSI) (source: persi.or.id) shows that private hospitals have shown an increase in growth in the last six years, while public hospitals have shown a decline. The growth of public hospitals is only around $0.4 \%$, while the growth of private hospitals is $15.3 \%$. According to BPS, the fastest hospital growth during 2013 to 2015 was in the province of East Java. High competition accompanied by technological advances and the current environment requires hospital management to pay serious attention to hospital sustainability. People are getting smarter in choosing their preferences, especially those related to vital needs, including hospitals. Hospital is a necessity that, in its selection, requires 
consideration. In contrast to the selection of daily necessities, consumers do not consider many things (Andreasen, Kotler, \& Parker, 2008; G. Belch \& Belch, 2014).

Health care is a very complex profit business (Berry \& Bendapudi, 2007). Both state and international health institutions comparatively tightly regulate differences in the healthcare market. It makes it difficult for private hospitals to reach them. However, on the other hand, a consumer-centered healthcare system leads to a race to provide the best healthcare for patients between hospitals. It creates an increasing need for hospitals about the importance of marketing in health care organizations (Kotler, Shalowitz, \& Stevens, 2008).

Brand Image of health services of an international standard hospital and having and meeting international standard health care standards. The hospital's brand image must have the public perception, which is an image or image that is from opinions, reputations, and characteristics perceived by the community. Therefore, every health care organization such as the NHS must have a brand, whether intentionally created or not (Chahal \& Bala, 2012). Experiences and interactions with healthcare facilities and services, websites, or hospital employees shape their brand image daily. Although the formation of this brand image will occur naturally, branding techniques are still needed to help guide it in a more profitable direction both in terms of effectiveness and efficiency.

Branding efforts through integrated marketing communication activities carried out by the NHS can help health service organizations, namely hospitals, to be able to attract fundings to the talents of health services (doctors, nurses, and other employees). Through branding, hospitals gain alignment and employee engagement, as well as attracting and retaining patient loyalty. These tasks are critical to organizational success as the healthcare industry becomes competitive and patients seek the best options. Branding can also benefit the organization by showing the unique value of the hospital to the process of building an international hospital brand image like what the NHS does. It is a valuable tool that will communicate who the NHS is as a healthcare organization and where the NHS is going in the future.

As a national hospital with an international health service orientation, NHS continues to develop itself by improving the quality of services with international standards, including the quality of the doctors who practice in the hospital, not only the equipment and building facilities. With the phenomenon of problems in the NHS, this study tries to explore and explore descriptive analysis with a case study approach. The case study refers to the problems of the NHS in building an international hospital brand image. In contrast, the brand 
name used by the NHS is the Surabaya national hospital. This study will examine the integrated marketing communication strategy of the NHS in improving the brand image of an international hospital by analyzing the strategic concept and process of integrated marketing communication in building an international hospital brand image.

\section{METHOD}

This research uses a case study method with an exploratory qualitative (Yin, 2011, 2012) research approach to examine NHS brand image strategies through integrated marketing communication. Exploratory qualitative research intends to observe, understand, and explore the phenomena experienced by NHS hospitals in building and improving the brand image of international hospitals.

\section{Data Collection}

This study uses data collection techniques, namely in-depth interviews and observations, to obtain data to be analyzed. Data is a collection of evidence or facts that are collected and presented for a specific purpose. Data can also be interpretative as all information obtained from people using as informants and data from official documents and books related to the object of research, namely marketing communication strategies and integrated marketing communication practices in NHS hospitals.

In this case, data collection using primary and secondary data sources.

Primary Data Sources. A primary data source is the first source obtained where data is generating. In this study, primary data were obtained directly from the source through in-depth interviews with key informants, namely the hospital director, head of the marketing and public relations department to employees, or marketing and public relations staff at NHS hospitals.

Secondary Data Sources. Sources that do not directly provide data on data collection. Researchers use secondary data as a complement and support for primary data from observations at the research site and reports in the form of documents, regulations, and hospital policies related to international standard hospital brand image, documents related to integrated marketing communications that build an international hospital brand image. The observation and search for secondary data are: first, determine the object to observe first. It will be the limitation (focus) of the research and will narrow the observation space, which will save time and energy when the observation process begins. Second, determine the objectives and benefits of the research as the basis for searching for secondary data in observation. Third, to record in detail the incident (the integrated communication process carried out by the NHS) and related documents, be it reports, regulations to NHS policies related to integrated communication in building an international hospital brand image (Kristiyono, 2019).

The data collection technique in this research is the most strategic step. The main objective of this research is to obtain data on the strategic concept of marketing communication and the form of integrated marketing communication practices for NHS hospitals in building an international hospital brand image.

ISSN 2338 - 0861 (cetak); e-ISSN 2621 - 8712 (online)

website : http://spektrum.stikosa-aws.ac.id 
So the researchers determined data collection techniques that could produce data that met the data standards set. Exploratory qualitative research in this thesis research, data collection was carried out in natural conditions using observation, interviews, and documentation.

\section{Units}

This research will place primary data from interviews and secondary data from observations as the unit of analysis. The unit of analysis in this study is the first in the form of data from in-depth interviews with key informants, namely the hospital director as the strategic policyholder of the NHS Hospital, the head of the marketing department as the designer of the IMC strategy concept, and branding image from the NHS, and the public relations employee or NHS marketing staff as implementing IMC activities and branding image from the NHS.

In addition to in-depth interviews with key informants as the first unit of analysis, this study also places secondary data, namely the results of experimental observations at the research site (NHS), as the second unit of analysis. The unit of analysis obtained in this observation is in the form of reports in documents, regulations, and hospital policies related to international hospital brand image, documents related to integrated marketing communications that build an international hospital brand image.

\section{Data Analysis}

This data analysis process is the third stage in research activities. Qualitative data analysis in this study is conducting inductively. Namely, qualitative research does not start from theoretical deduction but starts from empirical facts. Researchers will go directly to the field, study, analyze, interpret and draw conclusions from phenomena in the field. Researchers face data obtained from the field, namely the empirical phenomenon of integrated marketing communication problems in NHS hospitals in building an international hospital brand image. From this data, the researchers analyzed to find meaning, which then became the result of the research (Andrologi \& SUGIARTO, 2014; Neuman, 2014).

The data analysis method is a stage in this research after data collection is complete. The data obtained will be processed to get answers to existing problems. Following the data obtained in this study, the researchers collected, classified the data obtained from the results of field data research, and then searched for theories related to the problems studied, namely an integrated marketing communication strategy to build an international hospital brand image. Then conclusions are drawn to determine the results. The results of the data analysis will then be presented descriptively, namely by determining the data and describing what is in detail according to the problem studied with the data obtained (Daymon \& Holloway, 2010).

\section{RESULT \& DISCUSSION National Hospital Surabaya Integrated Marketing Communications (IMC)}

There are many reasons why the marketing department of NHS adopt the concept of Integrated Marketing 
The Promotional Mix

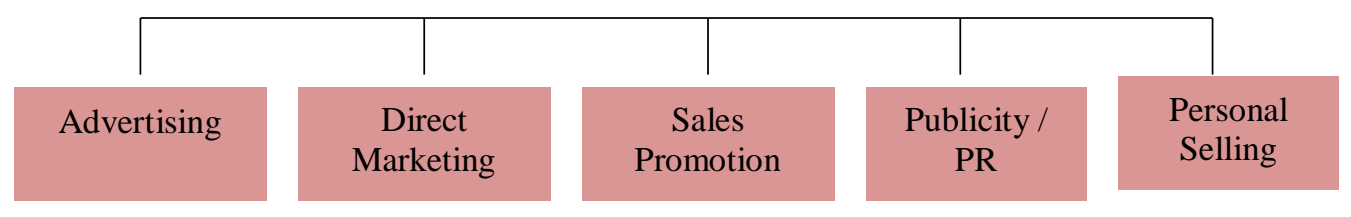

Fig. 1. Elements of the promotional

(source: Introduction to Advertising and Promotion: an Integrated Marketing

Communication Perspective (M. A. Belch \& Belch, 2008))

Communication (IMC) in their sales strategy. It also happens in the healthcare industry, namely hospitals. One of the reasons that become the basis is that marketers understand and recognize strategies integrating into various communication functions rather than running these communication functions alone. Integrated marketing communication, commonly called Integrated Marketing Communication (IMC), makes a product or brand, in this case, a hospital health service product that will be selling, can be communicated or informed quickly, and can use various communication media at once.

George Belch (2008) states that promotion has been defining as the coordination of all sales initiatives. The initiative to establish information channels and persuasively sell goods and services and promote ideas (G. Belch \& Belch, 2014; M. A. Belch \& Belch, 2008). The essential tools used to achieve the goals of marketing communications in health care organizations or agencies such as hospitals are often referred to as the promotion mix, including advertising, direct marketing, sales promotion, publicity/public relations, and personal selling.

The Publicity or Public Relations element is a nonpersonal marketing communication such as an organization, product, service, or idea that is not directly carried out by the sponsor or as a paid advertisement. It is usually in stories, news, editorialsannouncements about the company or organization and its products and services. Publicity or publicity is not always controlled or carried out by the company or organization concerned. Sometimes publicity is in the form of news or stories that are not good or unprofitable from the product, service, or company. A negative story about that product or company could do great harm or damage to that product, service, or company.

The last element in the promotional mix is Personal Selling, a form of person-to-person communication or commonly called interpersonal communication between sellers who help or carry out persuasive communication to prospective customers to buy or use the products and services or ideas 
offered. Personal communication, individual marketing communication that allows sellers to compose and create communication messages to consumers or potential buyers according to specific and situational consumer needs (Hughes \& Fill, 2007). Personal selling can also carry out a twoway communication process, namely receiving feedback from consumers, whether excellent or profitable or bad or unprofitable input for the company or product. Personal sales can modify messages so that they produce good things for the company. Improvement of products or services so that they can answer these consumers well.

\section{NHS Brand Image in Marketing Communication}

Public health service companies such as these NHS hospitals must create a brand image, or brand, in their market. To create a brand, a healthcare company such as a hospital must develop a message about its healthcare product or service. Communication messages through communication media (traditional and modern) must be repeating every time they communicate with their customer base, in this case, patients and prospective customers. Marketing communication is a fundamental and complex part of a hospital's marketing efforts. Freely defined, marketing communication describes all messages and media used to communicate with the market, in this case, the hospital's customers (patients and prospective patients). Marketing communications include advertising, direct marketing, branding, packaging, online presence, printed materials, public relations activities, sales presentations, sponsorships, exhibitions, and many more to promote products and services (Varey, 2002).

As for promotion, it uses marketing communication as a form of branding activity, namely Brand Awareness. It growing awareness of the existence of a product and service; Brand Knowledge, providing the information needed for the use of these products and services; Brand Likeability, fostering liking for the message conveyed; Brand Motivation, invites consumers to do what the communication message wants (Fan, 2010; Kristiyono et al., 2021). Next is Brand Believing, which is to build trust in the advantages of products and services. Brand Image strengthens the credibility of the brand or products and services; Brand Remembering, being able to recall the existence of these products and services. Furthermore, finally, Brand Loyalty, inviting consumers to continue to use the products and services communicated in Marketing.

This marketing communication theory becomes the rationale for processing data 
and analyzing the phenomenon of problems regarding strategic concepts in policy determination to the direction of marketing communication strategies carried out by NHS hospitals. This marketing communication strategy is the basis for marketing activities carried out by the NHS hospital's marketing and public relations department to carry out integrated marketing communications to build an international hospital brand image. It often revolves around the unique selling advantages of a particular product or service, such as healthcare, which may be low price, high quality, providing superior healthcare to patients or customers, specialized expertise by medical personnel, and others. To create a brand or brands based on expertise, a clothing maker might limit their line to running clothes. It brands the company as an expert in making activewear for runners. If the company later adds a line of children's clothing or maternity clothing, it undermines its claim to be an expert in sportswear and undermines its brand.

Brand or brand is a term closely related to the brand image and reputation of a product or place, which "captures the idea of reputation being observe, reputation being reward and reputation being managing." Simply put, a brand is "a product or service or an organization, considered in combination with its name, identity, and reputation"
(Anholt, 2010). As a trusted international standard hospital such as the NHS, branding is the process of promoting a superior product or service that is selected to build a good reputation in terms of an international hospital brand image. Branding plays a role in most political, social, and cultural life, official and unofficial, private and public, including the health sector (Vinodhini \& Kumar, 2010). Brand Image in the health care and service system revolves around trust and familiarity to create a brand image different from competitors, along with core benefits such as quality of service, world-class care, best doctors, and medical equipment. There are other essential aspects that hospitals should focus on branding elements such as hospital colors, themes, positioning, and identity, directly related to human physiological behavior.

\section{Discussion}

Branding strategies are emotionally connecting about how patients or society feel, hope, perform, dream about the hospital. It is a promise to provide tangible and intangible benefits to people in need of health services. Empathy also plays a vital role in the Hospital Heartbeat concept. The doctor must ensure that it has a positive mental impact on the patient. While Chest Beat describes as a "selling" brand image of technical health data, this concept ignores Heartbeat in the healthcare and healthcare sector. 
For example, Levi's brand creates Heartbeats with a feeling of freedom and relaxation rather than with thread count or fabric data (technical data on product materials). In this way, branding engages with Heartbeat, which generates customer loyalty and involves factual data on sales concepts.

The hospital continues to develop the quality of service and the completeness of health care products. When the hospital is shifting into the healthcare industry, it is essential to understand the competitive advantage in the hospital industry as an evaluation in its industrial environment. Each hospital must consider the relevant industry strengths as it positions itself competitively and evaluate the resources and capabilities needed to achieve a competitive advantage in the hospital. Hoskisson (1999) identifies one of the most significant theoretical contributions to the strategic management literature as incorporating industrialorganizational economics, particularly structure-behaviorperformance (SCP). It also applies to today's modern strategic management (Hoskisson, Wan, Yiu, \& Hitt, 1999).

A company's performance is related to the forces that determine the structure of the health environment industry. Concerning the general hospital industry, significant changes in its structure have occurred in the last few decades. Managed health care and services were introduced in the early 1980 s to cope with the explosion. The growth in health care expenditures has led to the creation of many health care buyers who then coordinate with hospitals and other related organizations (Teisberg, Brown, \& Porter, 1994).

As a result, managed healthcare has had an enormous impact on the structure of the healthcare industry because these empowered healthcare users have stimulated intense competition with and between hospitals. Health care management and hospital competition are two major competitive forces that are changing the structure of the healthcare industry and have a significant impact on hospital profitability. Therefore, this study will explore the impact of hospital competitive strengths in an integrated marketing communication strategy (IMC) in building an international hospital brand image. One of the competitive impacts is the competition between hospitals, how the NHS hospital positioned itself as an international hospital by implementing an integrated marketing communication strategy.

\section{CONCLUSION}

The main problem arises inhospital services, which have developed into an industry and are profit-oriented. This problem places a powerful emphasis on the cost 
dimension of private hospitals by the primary supplier groups of products and services to the industry, namely medical practitioners (doctors), nursing staff, and medical equipment suppliers. Therefore, a critical and sustainable management skill is that operating a hospital with acceptable quality standards and cheaper resources is constant operational innovation. Another dimension of hospital industry management is actively managing problems that arise by increasing the proportion of services with higher profit margins. Strategic management skills will become more critical as pressure increases to find future revenue and growth opportunities. These opportunities will come through various combinations of introducing new healthcare products and services, increasing penetration into highpriority market segments, or accessing new markets that are not currently served (Dafny, 2014).

These opportunities may be in areas closely related to existing business definitions such as diagnostics, post-treatment services, hospital improvement services, and others. The industry could also include more diverse opportunities than the traditional private hospital business, such as; elderly care, preventive health care, 'fitness,' and disease prevention services. The ability to make strategic change a reality will depend on the marketing skills applied. Once strategic priorities are setting, detailed marketing objectives and strategies need to be formulated and implemented with cost accountability and key performance indicators used to track and monitor progress (Gowrisankaran, Nevo, \& Town, 2015). The hospital health service, which has become a profit-oriented hospital industry, provides its penetration and problems in the marketing of health products and services provided by hospitals. An accurate marketing strategy is needed, primarily how to provide information on superior health services from the hospital and communicate it to the public. Community users of health services (patients) and the general public.

\section{BIBLIOGRAPHY}

Andreasen, A. R., Kotler, P., \& Parker, D. (2008). Strategic marketing for nonprofit organizations. Pearson/Prentice Hall Upper Saddle River, NJ.

Andrologi, F., \& SUGIARTO, Y. (2014). Analisis Pengaruh Brand Image dan Brand Awareness Terhadap Brand Loyalty dan Dampaknya Terhadap Brand Equity. Fakultas Ekonomika dan Bisnis.

Anholt, S. (2010). Definitions of place branding-Working towards a resolution. Springer.

Belch, G., \& Belch, M. (2014). The role of new and traditional media in the rapidly changing marketing communications environment. International Journal of Strategic Innovative Marketing, 1(3), 130136.

Belch, M. A., \& Belch, G. E. (2008). Integrated Marketing Communications. The International Encyclopedia of Communication.

Berry, L. L., \& Bendapudi, N. (2007). Health care: a fertile field for service research. Journal of Service Research, 10(2), 111-122.

Chahal, H., \& Bala, M. (2012). Significant components of service brand equity in 
healthcare sector. International Journal of Health Care Quality Assurance.

Cindya Yunita, C. Y. P. (2020). Marketing Communication Strategy in Building Awareness Environmental Friendly Products in PT. Virtus Venturama: (Studi Kasus Pada PT.Virtus Venturama). Jurnal Spektrum Komunikasi, 8(2), 149-158. https://doi.org/10.37826/spektr um.v8i2.89

Dafny, L. (2014). Hospital industry consolidation-still more to come. N Engl J Med, 370(3), 198199.

Daymon, C., \& Holloway, I. (2010). Qualitative research methods in public relations and marketing communications. Routledge.

DONAHUE, K. T., \& Vanostenberg, P. (2000). Joint Commission International accreditation: relationship to four models of evaluation. International Journal for Quality in Health Care, 12(3), 243-246.

Fan, Y. (2010). Branding the nation: Towards a better understanding. Place Branding and Public Diplomacy, 6(2), 97-103.

Gowrisankaran, G., Nevo, A., \& Town, R. (2015). Mergers when prices are negotiated: Evidence from the hospital industry. American Economic Review, 105(1), 172203.

Hermawati, T., Utari, P., \& Arifin, H. (2013). Strategi Komunikasi Pemasaran Rumah Sakit Sebagai Upaya Peningkatan Publisitas. J Spirit Publik, 1-16.

Hoskisson, R. E., Wan, W. P., Yiu, D., \& Hitt, M. A. (1999). Theory and research in strategic management: Swings of a pendulum. Journal of
Management, 25(3), 417-456.

Hughes, G., \& Fill, C. (2007).

Redefining the nature and format of the marketing communications mix. The Marketing Review, 7(1), 45-57.

Kotler, P., Shalowitz, J. I., \& Stevens, R. J. (2008). Strategic marketing for health care organizations: building a customer-driven health system. John Wiley \& Sons.

Kristiyono, J. (2019). KOMUNIKASI GRAFIS Dilengkapi Panduan Teknis Desain Layout dengan Aplikasi Software Grafis InDesign.

Kristiyono, J., Patriagama, M. R., Atma, A., Septyan, I., Hanafi, R., \& Asrori, H. S. (2021). Pengembangan Digital Branding Kampung Hidropononik Medokan Ayu Surabaya. Prapanca: Jurnal Abdimas, 1(1), 46-59.

Lipiäinen, H., \& Karjaluoto, H. (2015). Industrial branding in the digital age. Journal of Business and Industrial Marketing, 30(6).

Nabilah, R. Z. G., Bintoro, D. K., Indrawan, Y. R., \& Hariyanti, N. (2020). Gastrodiplomasi Sebagai Strategi Pengembangan Potensi Pariwisata Yogyakarta. CHANNEL: Jurnal Komunikasi, 8(1), 37-42.

Neuman, W. L. (2014). Basics of social research. Pearson/Allyn and Bacon.

Teisberg, E. O., Brown, G., \& Porter, M. E. (1994). The Key to HealthCare Reform: Innovation, Information, and Competition. Antitrust L. \& Econ. Rev., 25, 63.

Varey, R. J. (2002). Marketing communication: Principles and practice. Psychology Press.

Vinodhini, Y., \& Kumar, B. M. (2010). Brand equity in hospital marketing. International Journal

ISSN 2338 - 0861 (cetak); e-ISSN 2621 - 8712 (online)

website : http://spektrum.stikosa-aws.ac.id 
of Management Prudence, 1(2), 89.

Yin, R. K. (2011). Applications of case study research. sage.

Yin, R. K. (2012). Case study methods.

References

Andreasen, A. R., Kotler, P., \& Parker, D. (2008). Strategic marketing for nonprofit organizations. Pearson/Prentice Hall Upper Saddle River, NJ.

Andrologi, F., \& SUGIARTO, Y. (2014). Analisis Pengaruh Brand Image dan Brand Awareness Terhadap Brand Loyalty dan Dampaknya Terhadap Brand Equity. Fakultas Ekonomika dan Bisnis.

Anholt, S. (2010). Definitions of place branding-Working towards a resolution. Springer.

Belch, G., \& Belch, M. (2014). The role of new and traditional media in the rapidly changing marketing communications environment. International Journal of Strategic Innovative Marketing, 1(3), 130136.

Belch, M. A., \& Belch, G. E. (2008). Integrated Marketing Communications. The International Encyclopedia of Communication.

Berry, L. L., \& Bendapudi, N. (2007). Health care: a fertile field for service research. Journal of Service Research, 10(2), 111-122.

Chahal, H., \& Bala, M. (2012). Significant components of service brand equity in healthcare sector. International Journal of Health Care Quality Assurance.

Dafny, L. (2014). Hospital industry consolidation-still more to come. N Engl J Med, 370(3), 198199.

Daymon, C., \& Holloway, I. (2010). Qualitative research methods in public relations and marketing communications. Routledge.

DONAHUE, K. T., \& Vanostenberg, P. (2000). Joint Commission International accreditation: relationship to four models of evaluation. International Journal for Quality in Health Care, 12(3), 243-246.

Fan, Y. (2010). Branding the nation: Towards a better understanding. Place Branding and Public Diplomacy, 6(2), 97-103.

Gowrisankaran, G., Nevo, A., \& Town, R. (2015). Mergers when prices are negotiated: Evidence from the hospital industry. American Economic Review, 105(1), 172203.

Hermawati, T., Utari, P., \& Arifin, H. (2013). Strategi Komunikasi Pemasaran Rumah Sakit Sebagai Upaya Peningkatan Publisitas. J Spirit Publik, 1-16.

Hoskisson, R. E., Wan, W. P., Yiu, D., \& Hitt, M. A. (1999). Theory and research in strategic management: Swings of a pendulum. Journal of Management, 25(3), 417-456.

Hughes, G., \& Fill, C. (2007). Redefining the nature and format of the marketing communications mix. The Marketing Review, 7(1), 45-57.

Kotler, P., Shalowitz, J. I., \& Stevens, R. J. (2008). Strategic marketing for health care organizations: building a customer-driven health system. John Wiley \& Sons.

Kristiyono, J. (2019). KOMUNIKASI GRAFIS Dilengkapi Panduan Teknis Desain Layout dengan Aplikasi Software Grafis InDesign.

Kristiyono, J., Patriagama, M. R., Atma, A., Septyan, I., Hanafi, R., \& Asrori, H. S. (2021). Pengembangan Digital Branding

ISSN 2338 - 0861 (cetak); e-ISSN 2621 - 8712 (online)

website : http://spektrum.stikosa-aws.ac.id 
Kampung Hidropononik Medokan Ayu Surabaya.

Prapanca: Jurnal Abdimas, 1(1), 46-59.

Lipiäinen, H., \& Karjaluoto, H. (2015). Industrial branding in the digital age. Journal of Business and Industrial Marketing, 30(6).

Nabilah, R. Z. G., Bintoro, D. K., Indrawan, Y. R., \& Hariyanti, N. (2020). Gastrodiplomasi Sebagai Strategi Pengembangan Potensi Pariwisata Yogyakarta. CHANNEL: Jurnal Komunikasi, 8(1), 37-42.

Neuman, W. L. (2014). Basics of social research. Pearson/Allyn and Bacon.

Teisberg, E. O., Brown, G., \& Porter, M. E. (1994). The Key to HealthCare Reform: Innovation, Information, and Competition. Antitrust L. \& Econ. Rev., 25, 63.

Tresnawati, Y. (2021). Cinema XXI Brand Activity Using Instagram Social Media in Pandemic Era. Jurnal Spektrum Komunikasi, 9(1), 105 - 116. https://doi.org/10.37826/spektr um.v9i1.161

Varey, R. J. (2002). Marketing communication: Principles and practice. Psychology Press.

Vinodhini, Y., \& Kumar, B. M. (2010). Brand equity in hospital marketing. International Journal of Management Prudence, 1(2), 89.

Yin, R. K. (2011). Applications of case study research. sage.

Yin, R. K. (2012). Case study methods.

ISSN 2338 - 0861 (cetak); e-ISSN 2621 - 8712 (online) website : http://spektrum.stikosa-aws.ac.id 